ESA is monitoring carefully the development of Beagle 2 as its schedule needs to dovetail smoothly with Mars Express.

David Southwood

Director, Scientific Programme, ESA8, 10 Rue

Mario-Nikis, F-75738 Paris cedex 15, France

\section{Diversionary tactics in environmental debate}

Sir - The irrelevant observations by Stuart Pimm and Jeff Harvey about Bjørn Lomborg's book The Skeptical Environmentalist (Nature 414, 149-50, 2001) exemplify the unfortunate tendency of some environmental activists, when challenged with well-founded objections to the scientific validity of their alarmist claims about the state of the planet, to respond with such diversionary tactics as counting the number of footnotes cited by their critics, disparaging their critics' credentials and misrepresenting their views - everything, in short, but dealing honestly with the evidence.

In his book, for example, Lomborg presents a detailed analysis, based on widely accepted United Nations (UN) data, to show how the alarmists have been consistently wrong about the global population and food supply. Contrary to the predictions of impending catastrophe by Paul Ehrlich, Lester Brown and Pimm himself (who in 1998 told a meeting at the American Museum of Natural History that the world population might reach 40 billion by the end of the twentieth-first century), the data actually show that, over the past four decades, per capita food production has increased substantially, even in the developing world, while population growth has slowed so that the world population will level off at about 9 billion by mid-century.

Lomborg shows with devastating effect how the alarmists have been able to generate their forecasts only by extrapolating from very short-term or local negative trends, while disregarding the larger positive trends. Yet, instead of discussing this evidence, Pimm and Harvey simply attack Lomborg's credentials by attempting to associate him with the absurd view that an ever-growing population could be sustained for the next 7 billion years. Lomborg says no such thing, nor anything like it.

Similarly, Pimm and Harvey dismiss Lomborg's detailed, well-founded critique of exaggerated extinction-rate predictions with the ugly charge that this is morally equivalent to denying the Holocaust. Yet far from denying that loss of biodiversity and other environmental threats are occurring, Lomborg plainly states that these are indeed serious problems. What he is criticizing is the habitual exaggeration and white lies that have become the common currency of environmentalist advocacy (see the Correspondence by A. Trewavas, Nature 414, 581-582; 2001).

It is thus particularly ironic that Pimm and Harvey level the supercilious charge that Lomborg's book ("like a bad term paper", they say) cites secondary sources. Lomborg does indeed cite secondary sources - to provide examples of the exaggerations and distortions made by environmental activists. But to demonstrate the inaccuracy of these pronouncements, Lomborg cites primary sources such as UN data and articles in peer-reviewed scientific journals.

Lomborg's whole point is that the refusal of some environmental activists to deal honestly with the data harms the credibility of both environmental science and environmentalism. Pimm and Harvey in their review appear to have provided a further example in support of this thesis. Stephen Budiansky Black Sheep Farm, 14605 Chapel Lane, Leesburg, Virginia 20176, USA

\section{Bioweapon agents: more access means more risk}

Sir - In the News Review article "Bioweapons: Delivering death in the mail” (Nature 414, 837-838; 2001), you quote Stanford biophysicist Steven Block as opposing restrictions on access to bioweapons agents, endorsing having "a lot of terrific [biomedical] scientists working on the problem" and forecasting "a 'molecular arms race' between bioweapons developers and biodefence specialists".

We believe that increasing the number of institutions and people with access to bioweapons agents will increase the likelihood of their release. We find the idea of a government-sponsored, large-scale multi-site "molecular arms race" frightening, and likely to lead to disaster. (See also Opinion and News, Nature 414, 235 and 237-238; 2001.)

We recommend a moratorium on new permits for possession or transfer of bioweapons agents until the following measures are put in place: national or regional limits on numbers of laboratories permitted access to bioweapons agents; minimal containment requirements (BL3); minimal security requirements (video surveillance, entry guards, dual-key locks, personnel screening; requirement that two people should be present during any work); inventory-reporting procedures; and inspection and review procedures.

We believe that all laboratories without current permits, and/or not in compliance with the requirements above, should be required to transfer (under special permit) or destroy stored bioweapons agents.

This scheme would restrict access to bioweapons agents, but would not, in our view, unduly restrict biodefence-related research. Research in laboratories without access to bioweapons agents could be performed using non-pathogenic or moderately pathogenic species as simulants (for example using Bacillus subtilis, B. thuringiensis or B. cereus as simulants for $B$. anthracis), and/or through collaboration with laboratories permitted access.

This scheme is more restrictive than current official proposals. However, we believe that it represents the minimum required to provide a real increase in security. The National Institutes of Health has announced a major funding initiative for biodefence research. Without new restrictions, this initiative is likely to increase the number of institutions and people with access to bioweapons agents, and with training in production, handling and modification of these agents - and thus, perversely, to make us less secure. Richard H. Ebright ${ }^{*}$, Nancy D. Connell $\dagger$ *Howard Hughes Medical Institute, Waksman Institute, Department of Chemistry, Rutgers University, Piscataway, New Jersey 08854, USA

$\dagger$ Center for Biodefense, Lourenco Center for the Study of Emerging and Re-emerging Pathogens, New Jersey Medical School, Department of Microbiology and Molecular Genetics, UMDNJ, Newark, New Jersey 07103, USA

\section{How scientists can take the initiative in schools}

Sir - As a schoolteacher, I am in my own way pursuing the agenda of your Opinion article "Educating future scientists" (Nature $414,1 ; 2001)$. I direct a programme, the science research initiative, in which science students aged 16 and above take part in experimental research, in collaboration with universities. They also write for and produce a national magazine, $\mathrm{N}$-lighten, on contemporary science, and participate in a biennial conference to present their own discoveries and critically appraise those of others from schools, universities and industry.

In view of the declining numbers of graduates entering careers in science, I strongly endorse your view that the practitioners of science are ideally placed to enthuse students in schools with the excitement of modern discoveries and their implications.

Mo Afzal

The King's School, Canterbury, Kent CT1 2ES, UK 